THE INTERNATIONAL

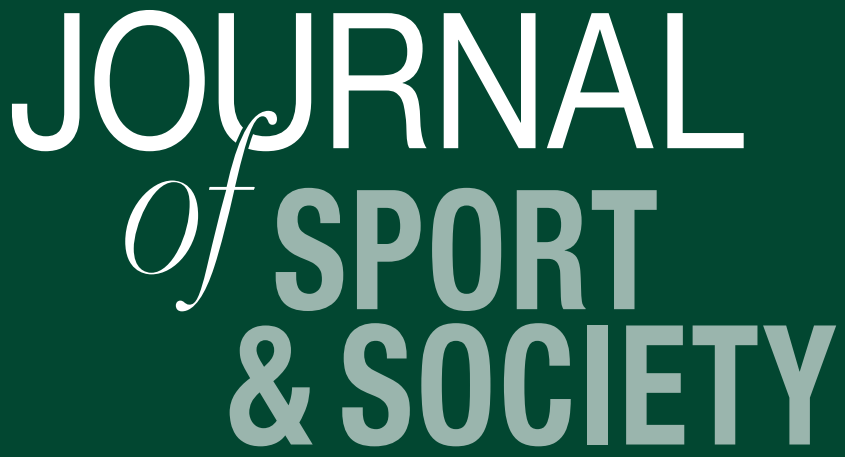

Volume 1, Number 3

A Faustian Contract? When a Sports Star's Media Coverage Goes Bad

Cathy Jenkins 
THE INTERNATIONAL JOURNAL OF SPORT AND SOCIETY

http://www.SportandSocietyJournal.com

First published in 2010 in Champaign, Illinois, USA by Common Ground Publishing LLC www.CommonGroundPublishing.com.

(C) 2010 (individual papers), the author(s)

(C) 2010 (selection and editorial matter) Common Ground

Authors are responsible for the accuracy of citations, quotations, diagrams, tables and maps.

All rights reserved. Apart from fair use for the purposes of study, research, criticism or review as permitted under the Copyright Act (Australia), no part of this work may be reproduced without written permission from the publisher. For permissions and other inquiries, please contact

<cg-support@commongroundpublishing.com>.

ISSN: 2152-7857

Publisher Site: http://www.SportandSocietyJournal.com

THE INTERNATIONAL JOURNAL OF SPORT AND SOCIETY is peer-reviewed, supported by rigorous processes of criterion-referenced article ranking and qualitative commentary, ensuring that only intellectual work of the greatest substance and highest significance is published.

Typeset in Common Ground Markup Language using CGCreator multichannel typesetting system

http://www.commongroundpublishing.com/software/ 


\title{
A Faustian Contract? When a Sports Star's Media Coverage Goes Bad
}

\author{
Cathy Jenkins, Griffith University, Queensland, Australia
}

\begin{abstract}
Belsey (1992:85) wrote that those seeking publicity cannot claim the protection of privacy when the publicity goes sour and they "...discover the negative side of the Faustian contract ..." A prominent sporting figure who has recently seen both sides of that contract is international golfing star Tiger Woods, who has had to deal with ongoing sensational media coverage of his personal life. This paper examines the coverage of Woods and how his attempts to keep his personal life out of the public gaze might have further impacted on his public image, and his relationships with the media and with sponsors. It argues that these attempts to delay the confirmation and even the publication of the media stories may have done further damage to his image. The paper also examines the tension between a sporting personality's need for publicity and their desire to keep their private life private.
\end{abstract}

Keywords: Crisis Management, Sports Journalism, Sports Media, Public Relations, Privacy, Tiger Woods

\section{Introduction}

$\mathrm{U}$

NTIL THE EVENTS that started in the week of Thanksgiving Day 2009, the image that Tiger Woods enjoyed was a public relations and marketing dream. This was a talented and glamorous man at the top of his sport, boasting a photogenic family and stressing the importance of his family life. Shortly before the news broke of his car accident and extramarital affairs, he had replied to a fan on his Facebook page that he found it hard to leave his family to travel to tournaments: "It's very difficult to leave Elin and the children, and I'm sure it's only going to get tougher" (cited in Dahlberg 2009, n.p.). Because of this clean-cut image, Woods was considered one of the true 'nice guys' among the celebrity hierarchy. In the months following that time, Woods became the subject of intense media scrutiny over his extramarital affairs and the affect that the 'outing' of these affairs might have had on his standing in the international sporting arena, and on his relationships with sponsors and the public.

This paper will examine the evolution of the way in which Woods handled the media's interest in his private life, beginning with his attempts first to keep silent, then to give a prepared statement to a group of hand-picked journalists, to taking part in one-on-one interviews with selected broadcasters, and finally to opening up to the all-in media conference prior to the U.S. Masters at Augusta in April 2010. It argues that, far from mitigating the damage caused by the publication of his indiscretions, Woods's early determination to keep silent about, and then to deny, the allegations may have caused further damage to his reputation, and his eventual decision to discuss the situation may have marked the beginning of the rehabilitation of his reputation. It appears that while Woods was at first quite determined to keep his private life private, the pressure of the media, the continuing erosion of his 
reputation and the loss of sponsors led him to turn to crisis management techniques in an attempt to stop the slide. This paper will also examine the tensions between Woods's desire for privacy, despite his high profile as a public figure, and the media's desire to tell the story.

\section{Celebrity, the News and Privacy}

News coverage of celebrities, and particularly of celebrity scandals, was originally considered to be the preserve of the tabloids and celebrity magazines, and scholars including Turner (2004: 76) have examined the 'tabloidisation' of the media: "By its critics, the process of tabloidisation is usually considered to sacrifice information for entertainment, accuracy for sensation, and to employ tactics of representation which entrap and exploit its subjects ..." However Woods's stellar career as a golfer, and his image as a role model, saw the story of his infidelities leap from the tabloids and into the mainstream 'hard news' providers around the world, including the BBC in the United Kingdom, all of the major news networks in the U.S., and in Australia. Broadsheet newspapers covered the story alongside the tabloids. For this to happen, it appears that there was more to this story than simple prurient interest in a famous person's sex life. This story was also about the fracturing of a carefully developed and maintained public image of a devoted family man, and someone who had professed himself to be a role model: "I've been very blessed to have the opportunity to become a role model. Not too many people in this world have that opportunity" (Rosaforte, cited in Smart, 2005: 141). Indeed, Woods had not only been categorised as a sporting role model, but also a racial one: “... in a historical moment in which African American athletes are routinely characterized as engaging in non-familial sexual relations, Woods is represented as the embodiment of normal, immigrant-familial America" (Cole and Andrews, 2001: 83).

Given the high expectations that the public and the media held for Woods, it was inevitable that there would be a reaction when his infidelities came to light. Hinerman (2006: 456) argues that celebrity culture regularly includes the 'narrative of scandal,' which reaffirms the link between stardom and cultural values. "If we take as our starting place that the media scandal is a narrative of a disruption, where a particular set of acts is seen to violate the moral boundaries of a culture, then stars ... are likely candidates for morality tales. Such tales tell us about a culture's moral constraints and its moral values." Discussion of the morality or otherwise of a person's actions is, of course, a minefield. What is immoral to one person may be quite acceptable to another, and indeed some commentators and many fans pointed out that Woods had done nothing illegal, and that he had the right to keep the issue of his indiscretions within the privacy of his family. However it is clear that many others found his actions morally troubling, and some of his sponsors reacted to that disquiet by severing ties with him. Woods himself would later state that he believed his behaviour had been unacceptable and untrue to his own values (Woods 2009b). In addition, there was also disappointment by some at his failure to live up to the image that he had so carefully developed. In having his infidelities exposed, Woods found himself at the centre of a morality tale played out to a global audience.

However despite Hinerman's argument, the question must still be asked whether Woods the celebrity had the right to expect that his private life should remain private. Chadwick (cited in Hirst and Patching 2005) urges journalists to ask themselves whether the public interest (ie the public good as opposed to prurient interest) outweighs an individual's desire or need for privacy. In his Respecting Privacy Guidelines, Steele (1999: n.p.) acknowledges 
that journalists face a difficult task when dealing with privacy issues: "The challenge for journalists is to be professionally skilled and appropriately aggressive in seeking meaningful information that serves a legitimate public need to know, while being respectful and compassionate to those whose privacy may be intruded upon."

However Belsey (1992: 84-85) is quick to dismiss a celebrity's claim to privacy, since their use of the media in the good times is an integral part of their lives:

Here we find people created by publicity, who would not be who or what they are without this exposure ... All such people live on the press and off the press; they require publicity and would shrivel without it. Such people, who tend to live according to the maxim that all publicity is good publicity, cannot consistently claim the protection of privacy when they discover the negative side of this Faustian contract. When the publicity suddenly becomes painful ... claims to a private life shade quickly into hypocrisy.

There are those who would argue that Woods did not need the media to become a great golfer, and that is true to a point. His own natural talent and hard work have lifted him to the pinnacle of his sport. However his ability to attract and keep sponsors, and to attract high guest appearance fees, has also been enhanced by the previously clean-cut reputation which he had carefully protected and promoted. It can therefore be argued that the media were justified in covering Woods's private life, as it revealed more about the man behind the image which enabled him to attract so many fans and sponsorship dollars. The fact that some sponsors have since cut their ties with Woods as a result of this coverage supports this point.

Bok (1983) argued that public figures cannot always complain if they receive the sort of scrutiny that ordinary citizens would not normally expect to face. However previously Bok (1978) believed that those in public life have the right to keep their private lives private, but added that that they do not have the right to lie about their personal lives. This is arguably one of the issues that has affected Woods's reputation. In a statement he placed on his web site two days after the car accident, he labelled as irresponsible "the many false, unfounded and malicious rumors that are currently circulating about my family and me" (Woods 2009a, n.p.). While his statement did not specifically refer to the reports that he had been having an extramarital affair, the wording gave the distinct impression that he was referring to more than just the car accident in his criticism of the media coverage. Therefore it was not unreasonable for the reader to infer that he was also denying the allegations concerning his extramarital activities.

Davis (1999: 41) argues that if public figures know that bad publicity is about to break around them, they should reveal it themselves, since "... there is still a good chance that reporters and the public will discount the impact of the story if the object of the bad news proactively puts the facts out: 'If they helped put the story out, how bad could it be?'" Public relations experts asked for comment on the Woods statement all followed the same line that concealing the truth is not the best strategy: "And the truth always comes out, said Mike Paul, founder and president of MGP \& Associates PR. Evading an issue, Paul said, will only encourage people to dig further, to find evidence of what they assume or suspect to be true" (AP National Writer, 2009, n.p.). This continual digging only allows the story to drag on, as Woods has found, with the additional damage to his image that stemmed from his attempts to conceal the full story. 
Three days after Woods's first statement was published, another woman came forward with claims of an affair, which finally prompted Woods to admit to his infidelities, or "transgressions" as he termed them (Woods 2009b, n.p.). At the same time he repeated his view that these matters should be private, and appeared surprised at the level of interest that the story had generated:

But no matter how intense curiosity about public figures can be, there is an important and deep principle at stake which is the right to some simple, human measure of privacy. I realize there are some who don't share my view on that. But for me, the virtue of privacy is one that must be protected in matters that are intimate and within one's own family. Personal sins should not require press releases and problems within a family shouldn't have to mean public confessions.

Despite this protestation, as time went on it became clear that Woods realised that he would have to do that very thing. It took another two months and more allegations of infidelity, in addition to the loss of a number of sponsors, but on February 19 Woods made a public confession, albeit a tightly stage-managed one. On announcing plans for the event his agent revealed that it would not be a media conference, as there would be no questions allowed. Woods would speak to a room of invited friends, colleagues and associates while journalists could watch the event via video link from a separate location. As a public relations move, it backfired. Shanoff (2010, n.p.) summed up the disgust of many commentators:

And so tomorrow, Tiger will be speaking to friends and associates - in other words: toadies, who will nod their heads solemnly, pretending to accept his apology on behalf of the rest of us. It begs the question how they can see the podium from their particular angle of obsequiousness.

Included in that group is the "media" - Tiger's hand-picked sycophants who are allowed to attend the event, but will be humiliatingly shunted off to a side room, unable to ask questions. Why bother picking soft media sympathists to "participate" if he won't even allow the charade of letting them ask a few softball questions?

One month later Woods took another step on the road to repairing his relations with the media, allowing a number of broadcasters to hold one-on-one interviews with him. Only five minutes were allowed per interview, and Woods continued to stress that parts of the story would remain private between himself and his wife: what happened on Thanksgiving night; what led to the car accident; what form of treatment he had sought (it had been reported that he had received treatment for sex addiction). Woods apologised to friends, colleagues, the public, and children who had looked up to him (ESPN, 21 March 2010). And finally on April 5, Woods fronted a media conference in the lead-up to the Augusta Masters, where he allowed a range of questions from a large media pack.

His responses to the questions indicate that he was attempting to repair his image using techniques that are now common to crisis management. Miller and Heath (2004: 100) argue that repair to an image can be made through a number of tactics including: suffering, praising others, corrective action and apology. Woods has now apologised several times, through his web site, via the carefully staged video statement, the one-one-one interviews and the press conference at Augusta. In addition he has stressed that he has suffered for his transgressions, 
citing as low points having to admit his infidelities to his wife and mother, how far he had fallen from his core values and his parents' teaching, and missing his son's first birthday while undergoing treatment. He praised others, in particular his wife, but also his fellow golfers and those who have supported him. Finally he promised to take corrective action, first through continuing his treatment (although still refusing to say what the treatment was for), promising to return to his core values and promising to treat the sport of golf and his fans with more respect (Times Online, 6 April 2010).

In his analysis of the media conference, Robinson (2010: n.p.) listed what he called "the good, the bad and the ugly" aspects of Woods's performance. Among the "good" aspects noted were Woods taking sole responsibility for what had happened, promising to be more approachable to his fans and finally answering some of the questions that journalists had been waiting to ask. However as Robinson noted, one of the "bad" aspects of the conference was that: "There are still questions that he won't answer, which means that reporters will keep digging. He won't say whether he was on Vicodin or Ambien on Thanksgiving night. He cites the fact that local police have closed the case on his accident, but without fully explaining what happened."

\section{Can the Coverage be Justified?}

Christians et al (1987: 111) outline three moral principles that journalists must follow when covering the private lives of individuals:

1. Decency and fairness are non-negotiable

2. Redeeming social value

3. People's dignity should not be maligned in the name of press privilege

It was always going to be difficult for mainstream journalists (or indeed their tabloid counterparts) to be fair in their reporting of Woods's activities, since fairness requires that he be given the opportunity to tell his side of the story: something he resisted doing for several weeks, and at the time of writing his side of the story has not yet been completely told. Woods's dignity was certainly maligned in some quarters, and not just through the mainstream media. U.S. radio personality Howard Stern held a beauty pageant featuring all of Woods's alleged mistresses, while newspaper headlines included "Wife Went for Tiger Over Birdie," "Crouching Tiger, hidden hydrant" and "Was he fleeing the ire of the Tigress?" (Golfweek.com, 2010: n.p.). People on the social networking site Facebook can become fans of a page called "I slept with Tiger Woods too."

The most troubling question raised from the above three points is whether the media's outing of Woods's extramarital affairs had any redeeming social value. After all, plenty of people have affairs but don't find themselves splashed across the front page for doing so. What benefit to society came from the often sensationalist reporting? Somewhat surprisingly, Archard (1998: 90-93) argues that there is value in the idea of reporting on the private lives of those in the public eye, because it provides three benefits to society:

1. It defines a community and maintains its unity. Those with whom we gossip, and those about whom we choose to gossip, define the groups to which we belong. 
2. It reaffirms shared values within a community in that it puts pressure on those in public life to behave within society's rules. Those who do not do so then face public ridicule or censure.

3. It demystifies those with high public status. Essentially, by showing that they are no better or worse than the average person in the street, a more egalitarian and realistic view of those involved is presented.

Significantly, Archard also claims that in some cases, gossip alone is capable of revealing the more intimate aspects of prominent people's lives: "Exposing such aspects ... thus sheds light on the real nature of those whose fame and public status might represent them in other and misleading ways" (p.92).

In the case of Woods, the redeeming social value comes from the reinforcement of societal values and the reminder that this particular "star" is a human being who has his share of human frailties. Indeed, in a way he can still be seen as a role model in the way that he finally dealt with the scandal by admitting his indiscretions, attempting to repair the damage caused by his behaviour, and getting on with his career. Woods has certainly faced public ridicule and censure for his indiscretions, although many fans and some commentators have supported him and criticised the media for their treatment of him. During his first practice round at Augusta, a large crowd of fans reportedly gave Woods a "cordial" welcome, with some calling out "You're still the man, Tiger" and "Welcome back." Syrluga (2010: n.p.) commented that the practice round "... provided the opportunity for a baby step in Woods's public rehabilitation."

Since the U.S. Masters Woods has continued to work on that rehabilitation, and it appears to be paying off. Despite ongoing reporting on his now failed marriage and speculation about the amount his ex-wife may win from their divorce settlement, Woods is receiving an increasingly positive reception from his fans. In July Wogenrich (2010: n.p.) reported that more than 36,000 people packed the galleries at the AT\&T National in Philadelphia, and most of them wanted to see one person: "You know, the one with 14 majors whose life outside golf threatened to derail his livelihood on it. Turns out, that threat has yet to materialize. In fact, Thursday's opening round continued proving that, while Woods may have lost sponsors and fans in the esoteric world of public opinion, he hasn't lost them in his safe zone on the golf course." It appears that as Woods continues working to repair his image and rebuild his golfing career, the "nice guy' role model may be replaced with that of a man who learns from his mistakes.

\section{References}

AP National Writer (2009), 'Image gurus to Woods: Go public like Letterman.' Available online at http:/www.sportingnews.com/golf/article/2009-11-30/image-gurus-woods-go-public-letterman Accessed 2 February 2010.

Archard, David (1998), 'Privacy, the public interest and a prurient public,' in Kieran, Matthew (ed), Media Ethics. London: Routledge. Reprinted 2000.

Belsey, Andrew (1992), 'Privacy, publicity and politics' in Belsey, Andrew and Ruth Chadwick (eds), Ethical Issues in Journalism and the Media. London: Routledge.

Bok, Sissela (1978), Lying: Moral Choice in Public and Private Life. New York: Pantheon Books.

Bok, Sissela (1983), Secrets: On the Ethics of Concealment and Revelation. New York: Vintage Books. Reprinted 1989. 
Cole, C. L. and David L. Andrews (2001), 'America's new son: Tiger Woods and America's multiculturalism,' in David L. Andrews and Steven J. Jackson (eds.) Sports Stars: The Cultural Politics of Sporting Celebrity. Routledge: London

Dahlberg, Tim (2009) "Two weeks that shattered the legend of Tiger Woods," SFGate - San Francisco Chronicle online, 12 December 2009. Available online at: http://www.sfgate.com/cgibin/article.cgi?f=/n/a/2009/12/12/sports/s062742S18.DTL Accessed 18 March 2010.

Davis, Lanny J. (1999), Truth to Tell: Notes from my White House Education. New York: Free Press.

Golfweek.com (2010), 'Tiger Headlines from Around World. Available online at: http://www.golfweek.com/news/2009/nov/30/tiger-woods-headlines-around-world/Accessed 2 February 2010.

Hinerman, Stephen (2006), '(Don't) leave me alone: Tabloid narrative and the Michael Jackson childabuse scandal,' in P. David Marshall (ed.), The Celebrity Culture Reader. New York: Routledge.

Hirst, Martin and Roger Patching (2005), Journalism Ethics: Arguments and Cases. South Melbourne: Oxford University Press

'I slept with Tiger Woods too' Facebook page. Available online at: http://www.facebook.com/home.php?\#!/pages/I-slept-with-Tiger-Woods-too/369092005326?ref=ts

Millar, Dan P. and Robert L. Heath (2004), Responding to Crisis: A Rhetorical Approach to Crisis Communication. New Jersey: Lawrence Erlbaum Associates.

Robinson, Eugene (2010), 'The Good, the Bad and the Ugly from Tiger Woods's news conference,' 5 April 2010. Available online at http://voices.washingtonpost.com/postpartisan/2010/04/the_good_the_bad_and_the_ugly.html Accessed 6 April 2010

Shanoff, Dan (2010), 'Shanoff's WUC: Tiger Woods Still Doesn't Get It,' 18 February 2010. Available online at http://www.sportingnews.com/blog/the_sporting_blog/entry/view/56267/shanoffs_wuc_tiger_woods_still_doesnt_get_it Accessed 20 February 2010

Smart, Barry (2005), The Sport Star: Modern Sport and the Cultural Economy of Sporting Celebrity. London: Sage.

Syrluga, Barry (2010), 'Tiger Woods returns to friendly reception as Masters week begins at Augusta,' 6 April 2010. Available online at http://www.washingtonpost.com/wp-dyn/content/article/2010/04/05/AR2010040503163.html Accessed 30 June 2010.

Steele, Bob (1999), "Respecting privacy guidelines," Poynter Online. Available at: http://www.poynter.org/content/content_view.asp?id=4643\&sid=32 Accessed 4 February 2010.

Times Online (2010) 'Highlights from Tiger Woods's News Conference at Augusta,' 6 April 2010. Available online at http://www.timesonline.co.uk/tol/sport/golf/article7088559.ece Accessed 30 June 2010

Turner, Graeme (2004), Understanding Celebrity. London: Sage.

Wogenrich, Mark (2010), 'Tiger Woods is still the man to watch,' 1 July 2010. Available online at http://articles.latimes.com/2010/jul/01/sports/la-sp-golf-20100702 Accessed 1 July 2010.

Woods, Tiger (2009a), 'Statement from Tiger Woods,' 29 November 2009. Available online at http://web.tigerwoods.com/news/article/200911297726222/news/ Accessed 1 February 2010

Woods, Tiger (2009b), 'Tiger comments on current events,' 2 December 2009. Available online at http://web.tigerwoods.com/news/article/200912027740572/news/ Accessed 1 February 2010 


\section{About the Author}

Dr. Cathy Jenkins

Cathy worked as a radio journalist for 16 years, including five years as Sports Editor for a Brisbane radio station where she covered local, national and international sporting events. Cathy moved full-time into university teaching in 1998 and is now a Senior Lecturer in Journalism in the School of Humanities, and Deputy Dean (Learning and Teaching) in the Faculty of Humanities and Social Sciences at Griffith University. Her teaching areas include sports journalism, broadcast journalism and news reporting, and she has supervised student volunteers in the press centres of the 2001 Goodwill Games and the 2006 Commonwealth Games. Cathy's research interests include media ethics, journalism history and media coverage of female politicians. 


\section{JOURNAL LO SPOBT \& SOCLETY}

\section{EDITORS}

Keith Gilbert, University of East London, UK.

Bill Cope, University of Illinois, Urbana-Champaign, USA.

\section{EDITORIAL ADVISORY BOARD}

Mojca Doupona, University of Ljubljana, Ljubljana, Slovenia.

Mark Hargreaves, University of Melbourne, Melbourne, USA.

Jack Jedwab, Association for Canadian Studies, Montreal, Canada.

Sid Katz, University of British Columbia, Vancouver, Canada.

Richard Lichen, Beijing Sports University, Beijing, China.

Abdul Hafidz bin Haji Omar, University Technology Malaysia, Malaysia.

Otto J. Schantz, University of Koblenz, Landau, Germany.

Karin Volkwein-Caplan, West Chester University of Pennsylvania, West Chester, USA. Rhodri Williams, University of British Columbia, Vancouver, Canada.

Please visit the Journal website at www.SportAndSociety.com for further information about the Journal or to subscribe. 


\section{THE UNIVERSITY PRESS JOURNALS}

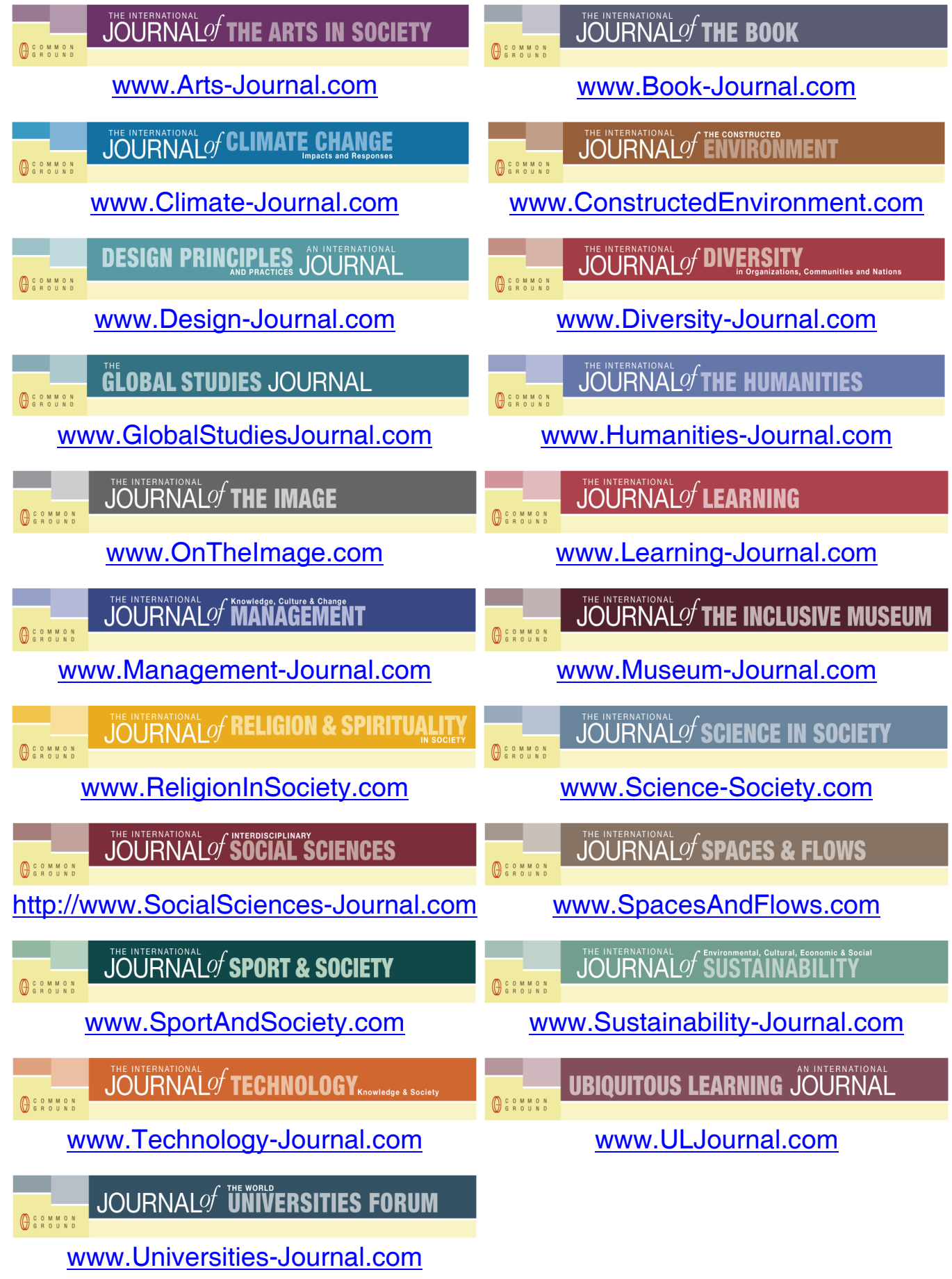

FOR SUBSCRIPTION INFORMATION, PLEASE CONTACT subscriptions@commongroundpublishing.com 